\title{
Destroying the Life and Career of a Valued Physician-Scientist Who Tried to Protect Us from Plague: Was It Really Necessary?
}

\author{
Barbara E. Murray, ${ }^{1,2}$ Karl E. Anderson, ${ }^{3}$ Keith Arnold, ${ }^{17, a}$ John G. Bartlett, ${ }^{8}$ Charles C. Carpenter, ${ }^{11,12}$ Stanley Falkow, ${ }^{13}$ \\ J. Ted Hartman, ${ }^{4, b}$ Tom Lehman, ${ }^{6}$ Ted W. Reid, ${ }^{5}$ Frank M. Ryburn, Jr., ${ }^{7}$ R. Bradley Sack, ${ }^{11}$ Marc J. Struelens, ${ }^{16}$ Lowell S. Young, ${ }^{14,15}$ \\ and William B. Greenough III,10 \\ 'Division of Infectious Diseases, Department of Internal Medicine, and ${ }^{2}$ Center for the Study of Emerging and Re-emerging Pathogens, University of Texas \\ Medical School, Houston, ${ }^{3}$ Department of Preventive Medicine and Community Health, University of Texas Medical Branch, Galveston, and ${ }^{4}$ School of Medicine \\ and ${ }^{5}$ Department of Ophthalmology and Visual Sciences, Texas Tech University Health Sciences Center, ${ }^{6}$ Department of Geosciences, Texas Tech University, \\ and ${ }^{7}$ Hospice of Lubbock, Lubbock, Texas; ${ }^{8}$ Division of Infectious Diseases, Department of Medicine, and Divisions of ${ }^{9}$ Medicine and ${ }^{10}$ Geriatric Medicine \\ and Gerontology, Johns Hopkins University School of Medicine, and "'Johns Hopkins Bloomberg School of Public Health, Baltimore, Maryland; "Brown Medical \\ School and ${ }^{12}$ Lifespan-Tufts-Brown Center for AIDS Research, Providence, Rhode Island; ${ }^{13}$ Department of Microbiology and Immunology, Stanford University, Stanford, \\ and ${ }^{14}$ Kuzell Institute for Arthritis and Infectious Diseases and ${ }^{15}$ Research Institute, California Pacific Medical Center, San Francisco, California; ${ }^{16}$ Microbiology \\ Laboratory, Hôpital Erasme, Brussels, Belgium; and ${ }^{17}$ International Clinical Research for Southeast Asia, Roche Research Foundation, Basel, Switzerland
}

Thomas Campbell Butler, at 63 years of age, is completing the first year of a 2-year sentence in federal prison, following an investigation and trial that was initiated after he voluntarily reported that he believed vials containing Yersinia pestis were missing from his laboratory at Texas Tech University. We take this opportunity to remind the infectious diseases community of the plight of our esteemed colleague, whose career and family have, as a result of his efforts to protect us from infection by this organism, paid a price from which they will never recover.

\section{SYNOPSIS OF OUR COLLEAGUE'S CAREER}

Dr. Thomas C. Butler has had a long and successful career that has focused on problems and illnesses of underprivileged persons, including those in the developing world and indigent patients in this country. He received a Bachelor of Arts degree from Johns Hopkins University in 1962 and a Doctor of Medicine degree from

Received 26 April 2005; accepted 26 April 2005; electronically published 29 April 2005.

a Retired.

b Dean emeritus.

Reprints or correspondence: Dr. Barbara E. Murray, Div. of Infectious Diseases, Dept. of Internal Medicine, University of Texas Medical School at Houston, 6431 Fannin St. MSB 2.112, Houston, Texas 77030 (bem.asst@uth.tmc.edu).

Clinical Infectious Diseases 2005; 40:1644-8

(C) 2005 by the Infectious Diseases Society of America. All rights reserved.

1058-4838/2005/4011-0011\$15.00
Vanderbilt University (Alpha Omega Alpha) in 1967, which was followed by an internship and residency in internal medicine at Johns Hopkins University during 1967-1969. He then served in the US Naval Medical Research Unit in 1969-1971, received a Vietnam Service Medal and a National Defense Service Medal in 1971, and was subsequently honorably discharged with the rank of lieutenant commander. Dr. Butler returned to Johns Hopkins University for an infectious diseases fellowship (1971-1973) and then was a member of the Hopkins faculty during 1973-1975. Dr. Butler moved to Case Western Reserve University in 1975, where he remained as an assistant professor and, later, as an associate professor until 1987, during which time he spent 4 years at the International Centre for Diarrhoeal Diseases Research in Dhaka, Bangladesh, where he was head of the Host Defense and the Pathogenesis-Therapy Working Groups and head of Dhaka Station Hospital. In 1987, he moved to Texas Tech University as Chief of the Infectious Diseases Department, a position he held until he was forced to resign in January 2004. His curriculum vitae lists $>170$ published peer-reviewed articles, reviews, and chapters, with his most important contributions being made in the areas of diarrheal diseases [1-18], typhoid fever [19-35], plague [36-67], and relapsing fever [68$74]$, as well as investigations of therapeutic modalities for other infectious diseases. His work in the late 1960s on oral rehydration therapy in Dhaka and Calcutta, India, resulted in one of the earliest articles describing the important clinical applications of basic physiologic studies of patients with cholera [14] and led to the first 
use of oral rehydration solution in a refugee camp in Calcutta in 1971.

\section{THE MOST UNEXPECTED TURN OF EVENTS}

Although the agent of plague, Yersinia pestis, is a potential weapon of bioterrorism, it is also endemic in the United States and many other parts of the world, as pointed out in all major texts and reviews, including some written by Tom Butler (e.g., chapters in the current and several past volumes of Principles and Practice of Infectious Diseases [52, 53, 64, 65], as well as other publications $[37,39-51,54,55,60$, $66,67,75])$. Indeed, as pointed out in Butler's 1983 monograph about plague, "In the United States during these same years (1970s), the number of human cases of plague increased several fold" [49, p. vii], and, on average, there are 2-15 known cases reported each year in the United States, with $\geqslant 40$ cases occurring in some years. A February 2005 health advisory from the Houston Area Health Alert Network concerning zoonotic plague in rats and cottontail rabbits in southern Midland County in West Texas also reminds us that plague is alive and well near Lubbock, Texas, the home of Texas Tech University and the Butler family.

Butler's work on plague, which includes published chapters, peer reviewed articles, and reviews [36-67, 75], goes back 35 years, to his service in the Vietnam War. His most recent project involving plague grew out of his realization that the antibiotics most often recommended to treat human plague (streptomycin, chloramphenicol, and tetracycline) are outdated, have problems with resistance, are in short supply, and/or are not ordinarily stocked by pharmacies. He believed it important to have clinical data to show that moremodern and widely available antibiotics could also effectively treat patients with clinical plague. In 2000, he began a collaboration with colleagues at the University of Tanzania in which he served as a consultant and provided a reference laboratory for a study designed to compare the efficacy of gentamicin and doxycycline therapy in clinically ill patients with Y.pestis infection. He initially used his own funds to help his Tanzanian colleagues get the study underway. The study was reviewed by Tanzania's medical research review board and was conducted at the University of Tanzania and under government authority; the institutional review board at Texas Tech University apparently exempted the project from review, because Dr. Butler was serving only as a consultant, without direct patient care responsibilities. The study was successfully completed; samples were provided to the US Army at Fort Detrick, Maryland, and the Centers for Disease Control and Prevention Laboratory in Fort Collins, Colorado; data were provided to the Food and Drug Administration; and a manuscript awaits publication. Because Dr. Butler's laboratory acted as a reference laboratory for the study, clinical and laboratory specimens were exchanged, and all original specimens were returned to Tanzania, as per contractual agreements.

In January 2003, Dr. Butler could not locate 30 vials of plague specimens and reported this to the safety officer at Texas Tech University; the Federal Bureau of Investigation (FBI) was notified by Texas Tech University, which resulted in $\sim 60 \mathrm{FBI}$ agents rapidly descending upon Texas Tech University and the briefing of government officials, apparently up to the level of President George W. Bush. According to reliable sources, Butler was questioned by FBI agents without legal counsel-which he waived, because he felt he had nothing to hide, he had worked with the military and federal agencies for years on this and other projects, and he genuinely wanted to help the FBI allay public fears. Testimony at the trial indicates that, after many hours of interrogation without sleep, and with the assurance that such interrogation would prevent any legal action, he signed a state- ment to the effect that the vials may have been autoclaved. He was then put in handcuffs and jailed, having been accused of lying to the FBI (a charge for which he was later acquitted). Jonathan Turley, an attorney for Butler and a professor at George Washington University School of Law, noted that "this made no sense. He would never have created a controversy to conceal the accidental destruction of vials" [quoted in 76]. After being incarcerated for 6 nights in county jail without bail, Butler was allowed to post bail of $\$ 100,000$ (which was later increased to $\$ 250,000$ ) but remained under house arrest, with electronic monitoring. He was not to contact colleagues who were on a witness list, and he had no access to his computer or e-mail for many months, despite having worked as Chief of the Infectious Diseases Department at Texas Tech University and lived in Lubbock for 16 years, where he and his wife were raising 4 children and enjoying much respect in the community.

Butler was offered a plea bargainwhich involved pleading guilty to lying and spending 6 months in jail-but declined and chose to risk trial by jury to clear his name. Although the original concerns of bioterrorism were not supportable, multiple additional charges largely unrelated to the disappearance of the vials containing Y. pestis were filed (i.e., "piled on"), including illegal transportation of plague bacteria, tax evasion, embezzlement, and fraud, for a total of some 69 charges carrying a maximum sentence of 469 years in prison and $\$ 17$ million in fines. Many of the charges had to do with contract disputes Butler had with his university (which are normally handled through civil, not criminal, proceedings) and were unrelated to the original charges associated with the disappearance of the vials. During the trial, prosecutors described Dr. Butler as an "evil genius" and compared him to "a cocaine dealer smuggling illegal drugs," and they emphasized the accusations of lying to the FBI and endangering the public and made repeated 
references to terrorism, actions many felt were designed to create an atmosphere of fear in the conservative West Texas courtroom.

Ultimately, a jury acquitted Butler of most of the original charges, including lying to the FBI, and the charge of tax evasion; he was convicted of charges related to 1 overseas shipment of an express-mail package containing "lab specimens" originally from Tanzania (a technical violation) back to his collaborators in Tanzania and of charges concerning contracts and indirect administrative charges associated with grants received from pharmaceutical companies. However, one of us (J.T.H.), the former dean of Texas Tech University who had helped recruit Butler, was aware of Dr. Butler's grants and consultancies and had encouraged him to finance his research and fund his salary with them. Testimony also indicated that others at Texas Tech University were aware of and/ or had signed his contracts; there were apparently no rules against such arrangements at the time, although new rules have been put into place since the trial. During his trial, members of the Texas Tech University administration testified against Butler, despite strong support from his colleagues and friends. The role of the Texas Tech University administration in the prosecution of Dr. Butler has been of great concern to faculty throughout the nation and is considered by many to be unprecedented. In attempts to explain this behavior toward a prominent and respected tenured faculty member, questions have been raised about pressures that may have been exerted on the university through its biodefense contracts with the Department of Defense.

At sentencing, District Judge Sam Cummings (variously dubbed "Hanging Sam" and "Maximum Sam," because of his record of imposing tough sentences) made numerous downward departures in sentencing Dr. Butler to less than the minimum set by federal guidelines, citing Dr. Butler's early work on treatment of diarrheal diseases and oral rehydration as hav- ing saved millions of children in developing countries and noting that Butler's tenure as a Texas Tech University faculty member (which included considerable care of indigent and HIV-infected patients) had provided more benefit than harm to the university. A direct quotation from the judge at the sentencing hearing, excerpted from the transcript, is as follows:

Number one, Texas Tech University Health Sciences Center would likely never have received any of the monies in question had the defendant not been in their employ. The grants and contracts have followed and have been attributed to the defendant's research and abilities and not that of Texas Tech University. Texas Tech University Health Sciences Center has received great prestige and recognition as a result of the defendant's medical research abilities, which substantially outweighs any potential harm brought upon Texas Tech University as a result of the defendant's actions in this case.... Number two, as noted in trial and sentencing testimony, the defendant's research and discoveries have led to the salvage of millions of lives throughout the world. There is not a case on record that could better exemplify a great service to society as a whole that is substantially extraordinary and is outside of anything the United States Sentencing Commission could have formulated in their devising of the guidelines governing departures regarding education and vocational skills, ... employment record, ... military, civic, charitable, or public service; employment related contributions; and record of prior good works as referred to in section $5 \mathrm{H} 1.11$ of the guidelines. It should be noted that the record adequately reflects these contributions to be exceptional in nature. [77]

In his numerous downward departures, the judge imposed a sentence of 2 years (to run concurrently), rather than the $\geqslant 10$-year sentence corresponding to his conviction, and a payment of approximately $\$ 38,000$ to Texas Tech University, rather than $\$ 1$ million. Many wrote to the judge urging a suspended sentence with community service; rumor has it that the judge did not do so out of concern that this would result in an automatic federal appeal for an even longer sentence.

Reactions in favor of Butler and expressions of concern about the handling and impact of the case have been strong, including comments from the Human Rights Committee of the National Academy of Sciences (NAS), the Institute of Medicine (IOM), the National Academy of Engineering, and the New York Academy of Sciences. The presidents of the NAS, the IOM, and the European Society of Clinical Microbiology and Infectious Diseases, as well as many prominent scientists and physicians, wrote to then Attorney General John Ashcroft to express their concern about the impact of the prosecution of Dr. Butler (the presidents of the NAS and the IOM had written only once before to an attorney general, Janet Reno, and their letter was concerned with the prosecution of Los Alamos National Laboratory scientist Wen Ho Lee). Four academy members who are Nobel Laureates wrote, on behalf of themselves, that "this respected colleague has been subjected to unfair and disproportionate treatment." Media coverage has been extensive; Science, The Scientist, The New York Times, The Los Angeles Times, The Baltimore Sun, BBC, CBS, and many other news sources have run stories suggesting that Butler may have been a victim of the widespread fear about (bio)terrorism and may have been singled out, presumably to serve as an example, as part of a flawed strategy to fight bioterrorism.

Setting aside the personal, emotional, and national climate of fear and paranoia, we think it makes very little sense to have removed from action such a knowledgeable and active clinician and clinical investigator who was working to protect us from plague-such removal is akin to shooting ourselves in the foot. We certainly agree that bioterrorism is a serious threat and that we should work hard to 
combat it. At the same time, if you or I develop plague tomorrow, we would like there to be an easily available antibiotic whose efficacy had been proven in a clinical trial, which is exactly the goal Dr. Butler set out to accomplish.

Dr. Tom Butler, a physician-scientist and member of the IDSA, respected by all colleagues who know him and his work, has been stripped of his professorship, tenure, salary, and medical license and has spent his life savings and retirement to defend himself. He has a wife (to whom he's been married for 25 years), 4 children (one recently graduated from Stanford, another recently graduated from the Massachusetts Institute of Technology, one is in junior high school, and one is in elementary school), and no sources of income. His situation is a cautionary tale to all of us, especially those who work with biological agents with potential for use in bioterrorism, even if in collaboration with governmental laboratories and scientists. Dr. Butler is appealing his conviction, and his friends and colleagues hope common sense will prevail and that he will be returned to action for our benefit, for the benefit of his patients, and for the benefit of many around the world who may be alive today because of what he has accomplished over a long and productive career.

Can we help Butler's situation? All concerned individuals can help Dr. Butler and discourage misuse of current laws designed to defend us against terrorism by writing to members of Congress, to the Department of Justice, or to the newly confirmed Attorney General Alberto Gonzales. Dr. Butler's appeal is currently pending in the US Court of Appeals for the Fifth Circuit. He is being ably defended by Jonathan Turley of Georgetown University and by Daniel Schwartz. He has exhausted his personal savings and retirement funds. If you wish to assist his defense by providing expenses for his appeal, donations to the Thomas Butler Legal Defense Fund may be sent to Daniel C. Schwartz, c/o Bryan Cave LLP, 700 Thirteenth St. NW, Washington, D.C. 20005.

\section{Acknowledgments}

Potential conflicts of interest. All authors: no conflicts.

\section{References}

1. Ahmed SM, Islam MR, Butler T. Effective treatment of diarrhoeal dehydration with an oral rehydration solution containing citrate. Scand J Infect Dis 1986; 18:65-70.

2. Butler T. Gastrointestinal infections. In: Hall B, Schmidt GA, Wood LDH, eds. Principles of critical care medicine. 2nd ed. New York: McGraw Hill, 1998:923-31.

3. Butler T. Shigellosis. In: Bennet JC, Phun F, eds. Cecil textbook of medicine. 20th ed. Philadelphia: W. B. Saunders, 1996:1647-8.

4. Butler T, Dunn D, Dahms B, Islam M. Causes of death and the histopathologic findings in fatal shigellosis. Pediatr Infect Dis J 1989; 8: 767-72.

5. Butler T, Islam M, Azad AK, Islam MR, Speelman P. Causes of death in diarrhoeal diseases after rehydration therapy: an autopsy study of 140 patients in Bangladesh. Bull World Health Organ 1987; 65:317-23.

6. Butler T, Islam MR, Azad MA, Jones PK. Risk factors for development of hemolytic uremic syndrome during shigellosis. J Pediatr 1987; 110:894-7.

7. Butler T, Islam MR, Bardhan PK. The leukemoid reaction in shigellosis. Am J Dis Child 1984; 138:162-5.

8. Butler T, Lolekha S, Rasidi C, et al. Treatment of acute bacterial diarrhea: a multicenter international trial comparing placebo with fleroxacin given as a single dose or once-daily for 3 days. Am J Med 1993; 94(Suppl 3A): 187S-194S

9. Butler T, Speelman P, Kabir I, Banwell J. Colonic dysfunction during shigellosis. J Infect Dis 1986; 154:817-24.

10. Kabir I, Butler T, Khanam A. Comparative efficacies of single intravenous doses of ceftriaxone and ampicillin for shigellosis in a placebo-controlled trial. Antimicrob Agents Chemother 1986;29:645-8.

11. Kabir I, Rahaman MM, Ahmed SM, Akhter $\mathrm{SQ}$, Butler T. Comparative efficacies of pivmecillinam and ampicillin in acute shigellosis. Antimicrob Agents Chemother 1984; 25 : 643-5.

12. Rabbani GH, Butler T, Shahrier M, Mazumdar R, Islam MR. Efficacy of a single dose of furazolidone for treatment of cholera in children. Antimicrob Agents Chemother 1991; 35:18647.

13. Rabbani GH, Islam MR, Butler T, Shahrier M, Alam K. Single-dose treatment of cholera with furazolidone or tetracycline in a double-blind randomized trial. Antimicrob Agents Chemother 1989; 33:1447-50.

14. Sack RB, Cassels I, Mitra R, et al. The use of oral replacement solutions in the treatment of cholera and other severe diarrheal disorders. Bull WHO 1970; 43:351.

15. Struelens MJ, Patte D, Kabir I, Salam A, Nath SK, Butler T. Shigella septicemia: prevalence, presentation, risk factors, and outcome. J Infect Dis 1985 ; 152:784-90.

16. Wanke C, Butler T, Islam M. Epidemiologic and clinical features of invasive amebiasis in Bangladesh: a case-control comparison with other diarrheal diseases and postmortem findings. Am J Trop Med Hyg 1988; 38:335-41.

17. Rabbani GH, Butler T, Knight J, Sanyal SC, Alam K. Randomized controlled trial of berberine sulfate therapy for diarrhea due to enterotoxigenic Escherichia coli and Vibrio cholerae. J Infect Dis 1987; 155:979-84.

18. Rabbani GH, Butler T, Bardhan PK, Islam A. Reduction of fluid-loss in cholera by nicotinic acid: a randomised controlled trial. Lancet $1983 ; 2: 1439-42$.

19. Butler T. Typhoid fever. In: Warren KS, Mahmoud AAF, eds. Tropical and geographical medicine. 2nd ed. McGraw-Hill, 1990.

20. Butler T. Typhoid fever. In: Bennett JC, Phun F, eds. Cecil textbook of medicine. 20th ed. Philadelphia: W. B. Saunders, 1996:1642-4.

21. Butler T. Typhoid fever. In: Rakel RE, ed. Conn's current therapy. 2nd ed. Philadelphia: W. B. Saunders, 1997:171-3.

22. Butler T. Typhoid fever. In: Goldman L, Bennett JC, eds. Cecil textbook of medicine. 21st ed. Philadelphia: W. B. Saunders, 2000:16813.

23. Butler T, Bell WR, Levin J, Linh NN, Arnold K. Typhoid fever. Studies of blood coagulation, bacteremia, and endotoxemia. Arch Intern Med 1978; 138:407-10.

24. Butler T, Islam A, Kabir I, Jones PK. Patterns of morbidity and mortality in typhoid fever dependent on age and gender: review of 552 hospitalized patients with diarrhea. Rev Infect Dis 1991; 13:85-90.

25. Butler T, Knight J, Nath SK, Speelman P, Roy SK, Azad MA. Typhoid fever complicated by intestinal perforation: a persisting fatal disease requiring surgical management. Rev Infect Dis 1985; 7:244-56.

26. Butler T, Linh NN, Arnold K, Adickman MD, Chau DM, Muoi MM. Therapy of antimicrobial-resistant typhoid fever. Antimicrob Agents Chemother 1977; 11:645-50.

27. Butler T, Linh NN, Arnold K, Pollack M. Chloramphenicol-resistant typhoid fever in Vietnam associated with $\mathrm{R}$ factor. Lancet 1973; 2:983-5.

28. Butler T, Rumans L, Arnold K. Response of typhoid fever caused by chloramphenicol-susceptible and chloramphenicol-resistant strains of Salmonella typhi to treatment with trimethoprim-sulfamethoxazole. Rev Infect Dis 1982; 4:551-61.

29. Butler T, Sridhar CB, Daga MK, et al. Treatment of typhoid fever with azithromycin versus chloramphenicol in a randomized multicentre trial in India. J Antimicrob Chemother 1999; 44:243-50.

30. Frenck RW, Nakhla I, Sultan Y, et al. Azith- 
romycin versus ceftriaxone for the treatment of uncomplicated typhoid fever in children in a randomized trial that included multidrug resistant infections. Clin Infect Dis 2000; 31: 1134-8.

31. Girgis NI, Butler T, Frenck RW, et al. Azithromycin versus ciprofloxacin for treatment of uncomplicated typhoid fever in a randomized trial in Egypt that included patients with multidrug resistance. Antimicrob Agents Chemother 1999; 43:1441-4.

32. Islam A, Butler T, Kabir I, Alam NH. Treatment of typhoid fever with ceftriaxone for 5 days or chloramphenicol for 14 days: a randomized clinical trial. Antimicrob Agents Chemother 1993; 37:1572-5.

33. Islam A, Butler T, Nath SK, et al. Randomized treatment of patients with typhoid fever by using ceftriaxone or chloramphenicol. J Infect Dis 1988; $158: 742-7$.

34. Roy SK, Speelman P, Butler T, Nath S, Rahman H, Stoll BJ. Diarrhea associated with typhoid fever. J Infect Dis 1985; 151:1138-43.

35. Tribble D, Girgis N, Habib N, Butler T. Efficacy of azithromycin for typhoid fever. Clin Infect Dis 1995; 21:1045-6.

36. Almeida CR, Almeida AR, Vieira JB, Guida $\mathrm{U}$, Butler T. Plague in Brazil during two years of bacteriological and serological surveillance. Bull World Health Organ 1981; 59:591-7.

37. Butler T. The black death past and present. 1 . Plague in the 1980s. Trans R Soc Trop Med Hyg 1989; 83:458-60.

38. Butler T. A clinical study of bubonic plague: observations of the 1970 Vietnam epidemic with emphasis on coagulation studies, skin histology and electrocardiograms. Am J Med 1972; 53:268-76.

39. Butler T. Plague. In: Conn H, ed. Current therapy. Philadelphia: W. B. Saunders, 1979:50-2.

40. Butler T. Plague. In: Strickland GT, ed. Hunter's tropical medicine. 7th ed. W. B. Saunders, 1991:408-16.

41. Butler T. Plague. In: Warrell DA, Cox TM, Firth JD, Benz EJ, eds. Oxford textbook of medicine. Oxford: Oxford University Press, 2000.

42. Butler T. Plague. In: Warren KS, Mahmoud AAF, eds. Tropical and geographical medicine. McGraw-Hill, 1984.

43. Butler T. Plague. In: Ledingham JGG, Warrell DA, eds. Concise Oxford textbook of medicine. Oxford: Oxford University Press, 1997.

44. Butler T. Plague. In: Rakel RE, ed. Conn's current therapy. Philadelphia: W. B. Saunders, 1995:107-8.

45. Butler T. Plague. In: Hunter GW, ed. Tropical medicine. 6th ed. W. B. Saunders, 1983.

46. Butler T. Yersinia infections. In: Wyngaarden JB, Smith JH, eds. Cecil textbook of medicine. 18th ed. Philadelphia: W. B. Saunders, 1988.
47. Butler T. Plague. In: Warren KS, Mahmoud AF, eds. Tropical and geographic medicine. 2nd ed. McGraw-Hill, 1990.

48. Butler T. Plague. In: Weatherall P, Ledingham JGG, Warrell DA, eds. Oxford textbook of medicine. 3rd ed. Oxford: Oxford University Press, 1996:595-9.

49. Butler T. Plague and other Yersinia infections. New York: Plenum Press, 1983:31-4. Greenough WB III, Merigan TC, eds. Current topics in infectious diseases.

50. Butler T. Plague and tularemia. Pediatr Clin North Am 1979; 26:355-66.

51. Butler T. Plague, human. In: Service M, ed. The encyclopedia of arthropod-transmitted infections. Wallingford-Oxon, United Kingdom: CABI International, 2000.

52. Butler T. Yersinia infections. In: Mandell GL, Douglas RG, Bennett JE, ed. Principles and practice of infectious diseases. 3rd ed. John Wiley and Sons, 1989.

53. Butler T. Yersinia infections. In: Mandell GL, Douglas RG, Bennett JE, eds. Principles and practice of infectious diseases. 4th ed. New York: Churchill Livingstone, 1995:2070-8.

54. Butler T. Yersinia infections: centennial of the discovery of the plague bacillus. Clin Infect Dis 1994; 19:655-61.

55. Butler T. Yersinia species. In: Yu VL, Merigan TC, Barriere L, eds. Antimicrobial therapy and vaccines. Baltimore: Williams and Wilkins, 1998:488-91.

56. Butler T, Bell WR, Nguyen Ngoc L, Nguyen Dinh T, Arnold K. Yersinia pestis infection in Vietnam. I. Clinical and hematologic aspects. J Infect Dis 1974; 129(Suppl):S78-84.

57. Butler T, Levin J, Do Quang C, Walker RI. Bubonic plague: detection of endotoxemia with the limulus test. Ann Intern Med 1973; 79:642-6.

58. Butler T, de Almeida CR, de Almeida AP, et al. Serological and experimental studies of plague in Northeastern Brazil [in Portugese]. Rev Bras Malariol Doencas Trop 1980; 32:2635.

59. Butler T, Levin J, Linh NN, Chau DM, Adickman M, Arnold K. Yersinia pestis infection in Vietnam. II. Quantiative blood cultures and detection of endotoxin in the cerebrospinal fluid of patients with meningitis. J Infect Dis 1976; 133:493-9.

60. Butler T, Mahmoud AA, Warren KS. Algorithms in the diagnosis and management of exotic diseases. XXV. Plague. J Infect Dis 1977; 136:317-20.

61. Butler T, Moller G. Mitogenic response of mouse spleen cells and gelation of limulus lysate by lipopolysaccharide of Yersinia pestis and evidence for neutralization of lipopolysaccharide by polymyxin B. Infect Immun 1977; 18:400-4.
62. Hudson BW, Wolff K, Butler T. The use of solid-phase radioimmunoassay techniques for serodiagnosis of human plague infection. Bull Pan Am Health Organ 1980; 14:244-50.

63. White M, Butler T. Pneumonia caused by plague and tularemia. In: Weinsten L, ed. Seminars in infectious diseases. Stratton Press, 1981.

64. Butler T, Dennis DT. Yersinia species, including plague. In: Mandell GL, Bennett JE, Dolin $\mathrm{R}$, eds. Principles and practice of infectious diseases. 6th ed., Vol. 2. Philadelphia: Elsevier, 2005:2690-700.

65. Butler T. Yersinia infections, including plague. In: Mandell GL, Bennett J, Dolin R, eds. Principles and practice of infectious diseases. 5th ed. 2000:2406-14.

66. Butler T. Yersiniosis and plague. In: Paimer SR, Soulsby L, Simpson DIH, eds. Zoonoses textbook. Oxford: Oxford University Press, 1998:281-93.

67. Butler T. Yersinia infections. In: Wyngaarden JB, Smith LH, eds. Cecil textbook of medicine. 17th ed. Philadelphia: W. B. Saunders, 1985: 1600-3.

68. Butler T. Relapsing fever. In: Strickland GT, ed. Hunter's tropical medicine. Philadelphia: W. B. Saunders, 1991:312-6.

69. Butler T. Relapsing fever. In: Strickland GT, ed. Hunter's tropical medicine and emerging infectious diseases. 8th ed. Philadelphia: W. B. Saunders, 2000:448-52.

70. Butler T. Relapsing fever. In: Wyngaarden JB, Smith LH, Bennett JC, eds. Cecil textbook of medicine. 19th ed. Philadelphia: W. B. Saunders, 1991:1771-2.

71. Butler T. Relapsing fever. In: Gorbach SL, Barlett JG, Blacklow NR, eds. Infectious diseases. Philadelphia: W. B. Saunders, 1992:1302-4.

72. Butler T. Relapsing fever. In: Wyngaarden JB, Smith LH, eds. Cecil textbook of medicine. Philadelphia: W. B. Saunders, 1985:1662-4.

73. Butler T. Relapsing fever. In: Warren KS, Mahmoud AAF, eds. Tropical and geographical medicine: McGraw-Hill, 1984.

74. Butler T. Relapsing fever. In: Hunter GW, Saunders WB, eds. Tropical medicine. 6th ed. 1983.

75. Butler T. Yersinia infections. In: Wyngaarden JB, Smith LH, Bennett JC, eds. Cecil textbook of medicine. 19th ed. Philadelphia: W. B. Saunders, 1991:1709-11.

76. George R. A poisonous kind of justice. The Independent. 31 August 2004. Available at: http://news.independent.co.uk/world/americas /story.jsp?story $=556734$. Accessed 29 April 2005.

77. United States v Butler, No. 5:03-CR-037-C (N.D. Tex. Mar. 10, 2004). Available at: http: //www.fas.org/butler/sentence.html. Accessed 29 April 2005. 


\section{ERRATUM}

An error appeared in an article published in the 1 June issue of the journal (Murray BE, Anderson KE, Arnold K, Barlett JG, Carpenter CC, Falkow S, Hartman JT, Lehman T, Reid TW, Ryburn FM Jr, Sack RB, Struelens MJ, Young LS, Greenough WB 3rd. Destroying the life and career of a valued physicianscientist who tried to protect us from plague: was it really necessary? Clin Infect Dis 2005;40:1644-8). The fourth sentence of the final paragraph should read "He is being ably defended by Jonathan Turley of George Washington University and by Daniel Schwartz" (not "He is being ably defended by Jonathan Turley of Georgetown University and by Daniel Schwartz"). The authors regret this error. 